\title{
IN RESPONSE TO "NEW ENGLISHES"
}

\section{Sinfree Makoni}

This paper angues that interest in "New Englishes" reflects a kind of proprietary interest in varieties of English, an interest which should be explained within a multidimensional approach which takes into account historical, economic, political and linguistic factors. Historically, the development of local varieties of English can be traced back to the British colonial language policy which encouraged the development of local languages and local varieties of English. Because of the nature of British colonial language policy, interest in "New Englishes" should be seen as part of the African scholar's attempt to react to her colonial inheritance.

Economically, interest in "New Englishes" is an attempt by African scholars to reduce their financial contributions to the British economy. African economies unintentionally subsidise the British economy when they rely heavily on language teaching materials and tests designed by British native speakers of English. Politically, when African scholars are documenting local varieties of English, they are striving to create a sense of national identity. National identity is an important issue in post colonial Africa because most African countries are states not nations. Linguistically, documentation of "New Englishes" is aimed at changing the varieties through corpus planning and, more importantly, it is a vote for restricted proficiency. Unfortunately, by describing localised varieties of English as nativised, linguists are depriving the "New Englishes" of the very legitimacy which they want to confer on them through their description. The term "nativised" is not only part of colonial discourse, but is also pejorative. The term has not yet been sufficiently rehabilitated in post colonial discourse in Africa for it to confer legitimacy.

Hierdie artikel beweer dat belangstelling in "New Englishes" 'n tipe besittende belangstelling in variëteite van Engels weerspieël, 'n belangstelling wat binne 'n multidimensionele benadering verduidelik behoort te word en wat historiese, ekonomiese, politieke en linguistiese faktore in ag neem. Histories blyk dit dat die ontwikkeling van plaaslike variëteite van Engels teruggevoer kan word na die Britse koloniale taalbeleid wat die ontwikkeling van plaaslike tale en plaaslike variëteite van Engels aangemoedig het. Uit 'n ekonomiese oogpunt is die belangstelling in "New Englishes" 'n poging deur Afrika-skoliere om hul finansiële bydraes tot die Britse ekonomie te beperk. Polities, wanneer Afrika-skoliere plaaslike variëteite van Engels dokumenteer, streef hulle daarna om 'n mate van nasionale identiteit te skep. Uit 'n linguistiese standpunt is die dokumentasie van "New Enlishes" 'n poging om die variëteite deur korpus-beplanning te verander en, belangriker, is dit ' $n$ stem vir die aanvaarding van beperkte taalvaardigheid. Deur die plaaslike variëteite van Engels as inheems te besknf, ontneem linguiste die "New Englishes" ongelukkig juis van die wettigheid wat hulle daaraan wil toeken deur hul beskrywing daarvan.

\section{Introduction}

The paper argues that in order to appreciate why African scholars have been fascinated for some time, and continue to be fascinated by "New Englishes", their scholastic activities have to be placed in a wider context which takes into account the impact of historical, economic, political and linguistic factors.

The historical aspect of the paper has three major aims. First, it outlines some of the factors which have given English its current position. Second, it argues that. an understanding of "New Englishes" is enhanced by examining the role of British colonial language policies. Thirdly, it demonstrates that the attempt to define "New Englishes" on 
the basis of the popular EFL/ESL distinction is unsatisfactory because of the inconsistencies in the way the terms are employed.

Guardians of standard English are not keen to legitimate localised varieties of English because this would threaten some of the economic advantages which accrue to them as native speakers of English. Politically, African scholars view their description of "New Englishes" as part of their contribution towards nation building. Linguistically, the description of "New Englishes" is part of language standardisation and is a quest for legitimacy. The paper concludes by examining the implications of the arguments outlined above for Zimbabwe.

\section{New Englishes and the problem of the ESL/EFL divide}

"New Englishes" is the term used to describe the English used in ESL countries (Kachru 1983). It is common practice in Britain to draw a distinction between ESL and EFL countries, with the label "New Englishes" restricted to countries labelled as ESL.

The term ESL is used to describe the English used in countries such as Zimbabwe, Nigeria, Kenya and Zambia. In such countries, although English is not a native language for the majority of the population, it is widely used in government, administration and creative writing. Another characteristic feature of ESL countries is the emergence of local varieties of English attributed partly to the widespread use of English and the absence of English native speaker influence. English is a foreign language in former Portuguese and Francophone colonies such as Mozambique and the Ivory Coast where it is taught as a subject, but is not the medium of instruction.

The attempt to define "New Englishes" with reference to ESL is most welcome because the distinction has educational and social significance. Unfortunately, the terms are used inconsistently (Phillipson 1991; 1992). One may cynically argue that the distinction between the terms is blurred because of their social and educational significance. It seems more accurate to speak of the various EFL/ESL situations in a particular area of the country rather than attempt to categorise the whole country 1 .

The categorisation of countries as either ESL/EFL is further complicated by the fact that some situations which are described as ESL may be recategorised as EFL depending on the ideological persuasion of the individual analyst. For instance, the Director of the Organization of African Unity of Inter-African Languages labels English and French as foreign languages (Mateene 1985 cited in Phillipson 1991). The description of English as a foreign language emphasizes English's alien nature because of its connection with British colonialism. Obviously, the labelling of English as a foreign language overlooks the degree to which English was used in African liberation struggles and continues to be used in the fight for a more democratic Africa (Bloor and Bloor 1990).

As pointed out earlier, another characteristic feature of "New Englishes" is the emergence of localised norms of usage, attributed in part to the absence of English native speaker influence. The absence of English native speaker influence in the so-called localised norms is more of a fiction than a reality. Although there are very few native speakers in most countries in which "New Englishes" are evolving, the physical absence of native speakers should not be construed to mean that there is no native speaker influence. The native speaker of English has been disembodied and technologised. Her physical presence is no longer necessary, because through the influence of institutions like the $\mathrm{BBC}$ and the Voice of America, the use of English in Africa is stronger than would have been the case if the native speaker were physically present. Commenting on the role of the BBC in promoting English native influence, Whitley (1971: 4) aptly observes: 
The English language is to be used to bind together the ruling bourgeoisie of the countries which Britain wishes to retain within her orbit of influence, whereas vernaculars are to be used to instigate counter-revolution in countries attempting to build socialism. Is this the reason that the $\mathrm{BBC}$ continues to use Swahili in its broadcasts to East Africa?

\section{English in its African and global context}

In order to understand the various sociolinguistic positions English currently occupies in the African context and the world, it is necessary to appreciate the current status English enjoys as an international language. English has a dominant though not exclusive position in science, medicine, computers and international diplomacy.

From a minor language in 1600 , English has in less than four centuries come to be the leading language of international communication in the world today. This remarkable development is ultimately the result of the 17 th, 18 th and 19 th century British successes in conquest, colonisation and trade (Troike 1977:2).

Not only is the presence of English in Africa an outcome of British colonialism and the spread of international capital, it is also a product of the concerted efforts of organizations such as the American Ford Foundation and the British Council. For instance, the British Council was set up in 1934 and granted a royal charter in 1940 "for the purposes of promoting a wider knowledge of the UK and the English language abroad and developing closer cultural relations between the UK and other countries" (Whitely 1971:4). The British Council not only spread English, but perhaps fuelled the myth of the native speaker as the ideal language teacher - a myth which is widespread and goes largely unchallenged because of the economic advantages which accrue to native speakers of English from it.

The status of English was boosted by the emergence of the USA as a major military and technological power in the aftermath of World War II. The technological might of the USA was felt not only in the spread of English, but in the type of language teaching methods which were used. For instance, audiolingualism had the strongest impact in countries which were technologically weak (Phillipson 1990), in as much as the impact of American capital was particularly felt in the poorest countries. Not only was English being spread, but particular language teaching methods and myths were also being promoted.

Contrary to the view Davies (1986) and Wardhaugh (1987) take, after gaining independence from Britain, African governments pursued policies which were only superficially different. The policies ranged from a complete retention of English as a medium of instruction in Kenya and Zimbabwe to a limited retention in Tanzania because of the latter's policy of Swahilization.

But the differences between the language policies of these countries, in spite of their ideological differences, were more apparent than real. English was a requirement for top jobs and university education, even in Tanzania in which English was for some time replaced by Swahili in primary and early secondary education.

Evidence of the continued importance of English is the increasing number of African elite whose children are acquiring English as a mother tongue, a phenomenon which has been observed in countries as far afield as Zimbabwe and Ghana (Makoni 1989; Chinebuah 1981). This challenges the argument that the English native speaker is on the retreat in Africa. The increasing number of African native speakers of English led Mazrui (1975) to predict (rather optimistically) that by the year 2000 there will be more Black people who speak English as a mother tongue in Africa than in Britain. What is interesting about Ali Mazrui's observation, however, is not the accuracy of his prediction but the sociolinguistic 
implications of language spread implied in his prediction. In some instances the spread of English is replacive and not additive; resulting in "linguicide" (Spolsky 1991)2.

Arguably, interest in "New Englishes" was forced on the agenda of language scholars by their realisation that the sun might not set on the "Empire of English". Through their documentation of "New Englishes", language scholars were unintentionally reinforcing the permanent status of English in Africa.

\section{New Frenches}

The situation of the French language in Africa is in many respects comparable to that of English, but there is one major difference. Both French and English are Languages of Wider Communication (LWC), partly because of their continued use in their former colonies, and their dominant role in international trade, diplomacy and academia.

There is, however, one major difference between French and English as LWCs. Interest in "New Frenches" in French applied linguistics is neither comparable to that of "New Englishes" in British applied linguistics, nor is the study of localised varieties of French as respectable an "area of academic enquiry" as the study of localised Englishes. This difference can be attributed to a large degree to the nature of British and French colonial language policies.

\section{Colonial language policies}

The disparity in the statuses of former colonial languages in their non-European contexts (i.e. in situations in which non-localised varieties are either evolving or have been institutionalised) can be traced to differences between British and French colonial policies, particularly where they related to language. The French pursued a policy of direct rule which placed emphasis on French, which was considered the language of "high culture". Local languages were treated with contempt (Wardhaugh 1987) ${ }^{3}$.

On the other hand, the British pursued a policy which, although similar to the French in aiming at distinguishing the coloniser from the colonised, encouraged the development of local languages in early educational instruction and literacy activities. In 1950, for instance, there were ten vernacular literature bureaux or committees in British Africa for the production of teaching and reading materials. Colonial officers were also encouraged to learn at least the African language of the region (unlike some of their modern British Council counterparts, who appear to be proud of their ignorance of the L1 of the countries to which they are posted). The recognition of local languages in British Africa was taking place in a triglossic situation in which standard English was the high form vis-a-vis the localised varieties of English. The latter, in turn, were regarded as more prestigious than the local indigenous languages. Interest in "New Englishes" is, arguably, an attempt by an African scholar to come to terms with her colonial intellectual inheritance.

\section{Language standardisation}

Standardisation may also play an important role in generating interest in "New Englishes". One dimension along which languages may differ is whether they are standardised or not. Even after being standardised, languages differ in the degree to which they are standardised, with the process of standardisation itself never fully complete, because languages are inherently dynamic. The extreme standardisation of the French language may be due to the functions of the French Academy (Academie Française). 
The extreme standardisation of French manifests itself in the insistence by the French on a metropolitan standard, which creates an "intolerance of dialects and languages within national borders, zenophobic national linguistic purity and an expansionist urge externally" (Phillipson 1991: 89). The legal measures employed by the French parallel those employed by Fascist regimes in Italy, Germany, and Spain. It is a sobering experience to realise that a country may be democratic, but its language policies fascist.

The high degree of dialectal intolerance in the standardisation of French created an atmosphere which militated against the recognition of local dialects of French in former French colonies ${ }^{4}$.

\section{The creation of new states and the emergence of "New Englishes"}

Wardhaugh's (1987) observation that "the reality of the modern world is that most states are not nations" is relevant to post-colonial Africa, where states were arbitrarily created during European colonialism. One of the many consequences of the arbitrariness with which colonial boundaries were drawn is that the same ethnic group would find itself split and consequently compelled to identify with groups drawn from diverse backgrounds - a sure recipe for national instability. Examples of groups split across many political boundaries abound in Africa.

Because of the diversity of ethnic groups within each state, feelings of national consciousness are at times salient by their absence. The absence of national feelings is an important element contributing to the frequent attempts at secession - a phenomenon quite common in Africa. The Nigerian and Ugandan civil wars and the military confrontation in Southern Zimbabwe in the mid-eighties were attempts at secession.

In a bid to manufacture feelings of national identity, African governments have frequently invented symbols such as national flags and anthems. The symbols are part of the attempts by African governments to convert states into nations. Nation formation, as Brass (1974) aptly observes, requires a "pool of symbols" and, arguably, "New Englishes" are part of the repertoire of symbols.

If the politicians reacted to the absence of feelings of national identity by creating national symbols, the academics responded in different ways to the quest for national identity, depending on their area of academic expertise. Just as historians chronicled the great achievements of past African states, such as tracing the origins of present day Zimbabwe to the Mhunhumutapa Empire, so language scholars have begun to identify patterns in oral and written texts which, if taken collectively, mark the text as either Ghanaian, Nigerian, Zimbabwean or African (Bokamba 1982; Owusu-Ansah 1991).

Although the documentation of "New Englishes" is linguistic, the functions which the documentation serves are political: it is a response by language scholars to the absence of national identity and an attempt to create one. In other words, the documentation of "New Englishes" is a linguistic task firmly rooted in nationalistic consciousness and sentimentality. Arguably, the attempt to alter the status of "New Englishes" through description parallels what British and American linguists sought to achieve through their description of nonstandard dialects of English. Stubbs (1986: 20) expresses the point quite forcefully when he says:

Descriptions of social reality become persuasive as soon as people
become aware of them. For example, the attention that linguists
have given to non-standard dialects of English, community languages
in Britain, and British and American sign language has changed the
status of these languages. Sometimes this has been the overt aim: to
attack the notion that such language varieties are in anyway
"primitive". But they mean that description becomes prescription 
due to dissemination... . there is no such thing as pure research on language and society. (The emphasis is mine.)

The description of fragments of "New Englishes" is an exercise in manipulating status planning through corpus planning.

\section{Localisation}

Localisation may contribute towards some of the interest by African scholars in "New Englishes". Localisation is an extremely powerful factor in most newly independent African countries. Localisation in some instances manifests itself as Africanisation.

Localisation operates on at least three different levels: staffing, content and approaches to content. In terms of staffing, most newly formed governments seek to replace the expatriate staff with locally trained personnel. Consistent with the localisation of staff, or strictly speaking as a result of it, is the localisation of content (subject matter). In most former British colonies this involves de-Europeanising the curriculum, hence the emergence of subjects such as African literature and African history. Interest in "New Englishes" is part of the general concern with studying something which is typically African, or non-European.

Research into localised varieties should be interpreted as an attempt by language scholars to achieve a level of linguistic localisation analogous to that found in African literature, and African history. But there is one major difference which is in danger of being overlooked between content subjects and language. There are native speakers of English, but there cannot be native speakers of African history and African literature etc. (unless one is using "native speaker" in a specialised sense to refer to "expertise in" as Paikeday 1989 does). Localisation of language cannot proceed in the same way as localisation of content subjects because of the native speaker. The absence of native speakers of history and literature facilitates domestication of those disciplines. Conversely, the presence of native speakers of English constrains its localisation in African contexts.

\section{The democratisation and ownership of English}

As pointed out above, linguistically, the "LOCALISATION" of English aims to achieve a level of linguistic independence commensurate with political independence. The idea of Zimbabwean English began to be mooted, as MacGinley (1987) points out, a number of years after the attainment of independence by Zimbabwe in 1980 .

Studies into localised varieties of English constitute an attempt to break away from the subordinate position which the emerging varieties occupy, if the view that English is "owned" by native speakers of English is maintained in Western Scholarship; hence the argument that "there is no national right of ownership attached to English. Any language is the property of the speech community that utilises it and English is now the property of many communities that transcend national boundaries and include native and non-native speakers alike" (Bloor and Bloor: 41). Bloor and Bloor's argument is echoed by a number of scholars including Strevens (1983) and more recently Greenbaum (1991).

Crystal (1985) puts the number of English native speakers in the core countries at about 350 million. The number of non-native speakers outside ranges from 300 to 1000 million. The "numbers game" is part of what Quirk (1989) cynically calls "liberation linguistics". The "numbers game" is designed to appeal to the democratic sentiments of the academic community, because, as the argument goes, if there are as many non-native speakers as there are native speakers, then the non-native speakers have as much right to English ownership as the native speakers do. Legally, the "numbers game" is designed to draw attention to the language rights of the non-native speaker. The language rights of the non- 
native speaker are part of the speaker's cultural and social rights. Expressed more emphatically, ownership of non-native varieties by second language users is as much part of their constitutional rights as are their social and cultural rights. In spite of the powerful nature of the "liberation linguistics" argument, one wonders how the putative number of speakers of English was arrived at, because census figures, which may be the potential source of such information, are notoriously unreliable in Africa. Furthermore, those who happily cite the number of non-native speakers of English do not identify what the minimum level of proficiency is that one has to acquire before being counted as a user of English. It is highly questionable to regard all users of English as having the right to own English irrespective of their proficiency in it.

\section{Economic considerations}

Sir Richard Francis, Director General of the British Council argues:

Britain's real black gold is not the North Sea oil but the English language. It has long been at the root of our culture and now is fast becoming the global language of business.

English has grown into one of Britain's major economic resources because of its status and role in international business. In order for Britain to fully exploit the status of English for the benefit of the UK, the native speaker is placed at the centre of English language teaching. The Director of the international house in London aptly summarises the situation in a brochure when he writes:

Once we used to send gunboats and diplomats abroad; now we are sending English teachers (p. 42 Economic Intelligence Unit).

Quirk (1989) reflects a similar view when he comments that some of the English teachers are qualified "through accident of birth, that they happen to be native speakers of English".

The financial benefits accruing to the UK, the USA etc, are threatened if Africa can claim "ownership" of the emerging varieties, for two reasons. Firstly, the language teaching materials meant for Africa will not be described with reference to standard English. Secondly, the English language examinations offered by the University of Cambridge will no longer be appropriate, and there are at least a quarter of a million candidates taking the Cambridge exams annually (Spolsky 1991).

During a period of recession such as is currently being experienced by the UK and the USA, the recognition of "New Englishes" in education in Africa could have adverse effects on the native speaker of English who benefits from the expanding English language teaching business. From an African perspective, interest in "New Englishes" is an attempt by African linguists to save African governments from unintentionally subsidising the UK and the USA.

\section{Education and the indigenisation of the teaching force}

In Zimbabwe, as elsewhere in Africa, the advent of independence after a prolonged period of colonial rule brought with it a rapid expansion in education, at least at the primary school level. Makoni (1989) points out that Zimbabwean primary education expanded tenfold in 1989. The rapid expansion in education has resulted in the majority of the pupils' being taught by non-native speakers of English whose proficiency in the target language is very low. One way of rendering the variety of English the speakers are using sociolinguistically respectable and educationally acceptable is to argue that the teachers are using a localised variety. The teachers themselves therefore become experts in the variety of English they are using, and consequently attempts to compare the local variety with 
standard English become misplaced. In Zimbabwe, it is not without sociolinguistic significance that the term "Zimbabwean English" gained popularity in some circles at the same time as some people began to complain about the falling standards of English (McGinley 1987).

Talk of "Zimbabwean English" or more boldly educational interest in the functional adequacy of English, it would appear to me, is an attempt to avoid addressing the issue of language in education, something which was not an issue earlier because there was very little education available.

The term "Zimbabwean English" is also ambivalent - an ambivalence which might be absent in the use of terms such as "Nigerian English" or "Ghanaian English". In Zimbabwe the term might refer not only to the English used by Africans, but to the English used by Zimbabweans of European descent - two types of English one might usefully keep separate.

\section{The illegitimacy of "New Englishes"}

A considerable amount of research effort is spent on documenting new varieties of English as a way of establishing their legitimacy. The description of these varieties as "the Other Tongue" or as "nativised" does, contrary to the expectations of the analysts, deprive these very varieties of the legitimacy which the analysts seek to achieve through their interventionistic descriptions which alter the objects of their description. Rampton (1990) succinctly sums up the situation when he suggests that by describing "New Englishes" as "the Other Tongue", Kachru and others are reinforcing the subordinate position of "New Englishes", because they describe the "New Englishes" using standard English - something which, theoretically, they would like to avoid, but in practice, reinforce.

The illegitimacy of the term "nativised" can be seen when it is contextualised in history. Makoni (1991: 18) contextualises the term thus:

During the colonial period, Africans were described as "natives" (see Phimister 1985). This is a term comparable in its pejorative force to "Kaffir, a term used by the South African White government to refer to the Blacks. From a Southern African perspective, it is a contradiction to argue that the English used by Africans is given legitimacy if it is called nativised. Nativisation of English delegitimises it.

Support for the existence of "New Englishes" comes from groups with conflicting ideological interests. The first group, as pointed out earlier, is made up of African academics who are interested in "New Englishes" for nationalistic reasons. The second group is made up of English purists who feel that non-native speakers cannot acquire standard English, so there is nothing to lose from encouraging the development of localised varieties of English because the varieties are not bona fide parts of the English language. Thus, the development of "New Englishes" is in itself a testimony to their inability to master English. The forging of an alliance between the extreme right and extreme left is not unique to the "New Englishes" controversy but is also characteristic of mother tongue teaching in the UK.

The rejection of localised varieties of English at the grassroots level arises from an awareness of TWO important factors:

1 Those who champion the cause of "New Englishes" are themselves experts in using standard English, as demonstrated by their ability to champion the "New Englishes" cause through standard English in international journals. 
2 The common person at the grassroots level feels that if "New Englishes" are used as language teaching models, she would be deprived of access to a variety which is used in academic and technological literature.

\section{Conclusion}

This paper has sought to identify political, historical, economic and linguistic factors which . may partly account for the continued interest by African scholars in "New Englishes". It has been argued in this paper that central to the whole debate is a kind of proprietary interest by linguists, teachers and other establishments. Another factor which is frequently overlooked in the debate about the legitimacy of "New Englishes" is the sociolinguistic significance the common person attaches to "New Englishes" in promoting her social advancement. 


\section{References}

BLOOR, Merriel and Thomas BLOOR. 1990. The role of English in resurgent Africa. In Language and power, British Studies in Applied Linguistics 5:32-44.

BOKAMBA, Eyamba G. 1983. The Africanisation of English. In Kachry, BB (Ed), The other tongue: English across cultures. Urban IL: University of Illinois Press:72-79.

BOKAMBA, Eyamba G. 1991. Sociolinguistic theories in the African context: An agenda for the 1990's. Paper presented at the sixth biannual international conference; University of Port Elizabeth, South Africa.

CHINEUA, Isaac K. 1981. Language policy and practice in education in Ghana. AILA Bulletin 2(30):8-36.

CRIPER-FREEDMAN, L. 1990. The tone system of West African Coastal English. World Englishes, 9(1):63-77.

DAVIES, Alan (Ed). 1986. Language education in Africa Seminar proceedings No. 26, Centre for African Studies, University of Edinburgh.

DAVIES, Alan (Ed). 1982. Introduction to special issue on language and identity. In Journal of multilingual and multicultural development, 3(3).

HUDSON, R. 1980. Sociolinguists. Cambridge, U.K.: Cambridge University Press.

KACHRU, BRAJ B (Ed). 1983. The other tongue: English across cultures. Oxford: Pergamon.

MAKONI, Sinfree B. 1989. Planning variability in second language acquisition. Unpublished $\mathrm{PhD}$ dissertation, Department of Applied Linguistics, University of Edinburgh.

MAKONI, Sinfree B. 1991. Post graduate researching in applied linguistics: reflections on applied linguistics post-graduate experience in the U.K.

MAZRUI, Ali. 1975. The political sociology of the English language: an African perspective. The Hague: Mouton.

McGINLEY, Kevin. 1987. The future of English in Zimbabwe. World Englishes, 6(2):159164.

NGARA, Emmanuel. 1982. Bilingualism and language education. Harare, Zimbabwe: Mambo.

OWUSU-ANSAH, Lawrence. 1991. Is it or is it not interlanguage: a head-on confrontation with non-native English. Edinburgh working papers in applied linguistics, 2:51-62.

PAIKEDAY, TM. 1985. The native speaker is dead. Toronto and New York:Paikeday Publishing.

PHILLIPSON, Robert. 1990. English language teaching and imperialism. Tronninge, Denmark: Transcultural. 


\section{http://perlinguam.journals.ac.za}

PHILLIPSON, Robert. 1991. Some items on the hidden second/foreign language acquisition. In Phillipson, Robert, Eric Keelerman, Larry Smith, Michael Sharwood Smith and Merrill Swain (Eds), Foreign/second language pedagogy research. Multilingual Matters: 38-52.

PHILLIPSON, Robert. 1992. Linguistic imperialism. Oxford University Press.

PLATT, John, H WEBER and ML HO. 1984. The new Englishes. London: Routledge and Kegan Paul.

PHIMISTER, Ian. 1988. An economic and social history of Zimbabwe. London and New York: Longman.

QUIRK, Randolph \& Henry G WIDDOWSON (Eds). 1985. English in the world: teaching and learning the language and literature. Cambridge: Cambridge University Press.

RAMPTON, Ben H. 1990. Displacing the native speaker: Expertise, affiliation and inheritance. English Language Teaching Journal, 44(2):97-101.

ROMAINE, Suzanne. 1984. The language of children and adolescents: the acquisition of communicative competence. Oxford: Blackwell.

SEY, Kof A. 1973. Ghanaian English: An exploratory survey. London: MacMillan.

STUBBS, Michael. 1986. Educational linguistics. London: Basil Blackwell.

STREVENS, Peter. 1983. The localised forms of English. In Kachru, BB (Ed), The other tongue: English across cultures. Urban IL: University of Illinois Press:2331.

SPOLSKY, Bernard. 1991. English and endangered languages. Paper read at a conference on Language in Venezuela.

TROIKE, R. 1977. The future of English. Editorial in The Linguistic Reporter, 14 February 1982. 


\section{End notes}

1 Zimbabwe is generally categorised as an ESL country (Ngara 1982), but the label unfortunately, overlooks the diversity of the sociolinguistic contexts within which English is used and learnt in that country. In urban Zimbabwe, on the one hand, the amount of English school-going children are exposed to is so rich and diverse that the situation is best described as an ESL situation. The situation is radically different in rural communities, where exposure is restricted exclusively to the classroom. In Zimbabwe, the ESL/EFL divide therefore corresponds to an urban/rural divide.

2 English is not only competing with some African languages as a mother tongue, it has also begun to win recruits from European languages in Africa such as Portuguese and French. Mozambique has increasingly begun to realise the advantages of English over Portuguese for full participation in some of the regional organisations. A majority of Mozambique's neighbours are English speaking, for example Zimbabwe, Zambia, South Africa, etc.

3 The French, however, were not consistent in the implementation of their policy. Phillipson (1991) points out that the French encouraged the development and use of local languages even in sub-Saharan Africa, particularly in countries such as Mali. As a rule, however, the French did not encourage the use of local languages.

4 If interest in "New Frenches" is difficult to cultivate because standardisation creates languages which are "pathological in their lack of diversity" (Hudson 1980: 34), it is possible to argue that "localisation" of English is likely to occur in those areas of English which are less standardised, because there is no language which is uniformly standardised.

Spelling, according to Stubbs (1986) is the most highly standardised area of the English language. Standard spellings are listed in major dictionaries. There are two major types of spelling, British and American. There are no studies to my knowledge into the nurture of spelling in "New Englishes". The majority of studies into New Englishes have concentrated on areas which are not highly standardised. Because use of the lexicon and pronunciation are less highly standardised, they permit a great deal of variability, hence are more susceptible to localisation. A considerable amount of work in "New Englishes" has focused on the lexicon and vocabulary (Sey 1973; Platt, Weber and Ho 1984; Criper-Freedman 1991; Bokamba 1991). 